\title{
Ractopamine Hydrochloride and Estradiol + Trenbolone Acetate Implants Alter Myogenic mRNA, $\beta$-Adrenergic Receptors, and Blood Metabolites
}

\author{
T. L. Harris' ${ }^{1}$, Z. K. Smith ${ }^{2}$, F. R. B. Ribeiro ${ }^{3}$, M. A. Jennings ${ }^{1}$, G. J. Vogel ${ }^{4}$, B. J. Johnson ${ }^{1 *}$ \\ ${ }^{1}$ Department of Animal and Food Sciences, Texas Tech University, Lubbock, Texas, USA \\ ${ }^{2}$ Department of Animal Science, South Dakota State University, Brookings, South Dakota, USA \\ ${ }^{3}$ Phytobiotics North America LLC, Cary, North Carolina, USA \\ ${ }^{4}$ Elanco Animal Health, Greenfield, Indiana, USA \\ Email: *bradley.johnson@ttu.edu
}

How to cite this paper: Harris, T.L., Smith, Z.K., Ribeiro, F.R.B., Jennings, M.A., Vogel, G.J. and Johnson, B.J. (2020) Ractopamine Hydrochloride and Estradiol + Trenbolone Acetate Implants Alter Myogenic mRNA, $\beta$-Adrenergic Receptors, and Blood Metabolites. Open Journal of Animal Sciences, 10, 447-467.

https://doi.org/10.4236/ojas.2020.103028

Received: May 3, 2019

Accepted: June 16, 2020

Published: June 19, 2020

Copyright $\odot 2020$ by author(s) and Scientific Research Publishing Inc. This work is licensed under the Creative Commons Attribution International License (CC BY 4.0).

http://creativecommons.org/licenses/by/4.0/ (c) (i) Open Access

\begin{abstract}
Two commonly used growth promotants in the United States beef industry are $\beta$-agonists and anabolic steroid hormones. Each has been shown to increase lean muscle deposition in cattle provided treatments of each growth technology, but much is still unknown of how steroidal implants and $\beta$-agonists work in combination. It was our goal to determine the effect of implant strategy and $\beta$-agonist administration in beef feedlot heifers $(\mathrm{n}=$ 264). A $3 \times 2$ factorial randomized complete block design was used with 2 levels of OPT and 3 different durations of terminal implant (TI) windows for a total of 6 treatment groups with 9 replications. Terminal implants $(20 \mathrm{mg}$ estradiol/200 mg trenbolone acetate implant, Component TE-200) were provided to heifers $140 \mathrm{~d}$ from slaughter (TI140), $100 \mathrm{~d}$ from slaughter (TI100), or $60 \mathrm{~d}$ from slaughter (TI60). Animals receiving the later two TI being first implanted on day 0 ( $8 \mathrm{mg}$ estradiol $/ 80 \mathrm{mg}$ trenbolone acetate implant, Component TE-IH). The second treatment of the cattle received was the orally active beta adrenergic agonist, ractopamine-hydrochloride (RH) in the form of Optaflexx $^{\circledR}$ (OPT; 0 (NO) or 200 (YES) $\mathrm{mg} / \mathrm{hd}^{\mathrm{d}} \mathrm{d}^{-1}$ ) over the final 28 days of the trial. Thirty animals were subjected to longissimus muscle (LM) biopsies on $\mathrm{d}$ $0,40,80,112$, and at slaughter on d 140 to view mRNA levels of myogenic related genes and protein quantities of the $\beta_{1}$-adrenergic receptor $(\beta 1 \mathrm{AR})$ and $\beta_{2}$-adrenergic receptor ( $\beta 2 \mathrm{AR}$ ). On the same days, blood samples were taken from 108 animals to assess changes in plasma blood urea nitrogen (BUN), non-esterified fatty acids (NEFA) and progesterone due to treatments. Relative mRNA levels of myosin heavy chain IIX (MHC IIX), AMPK $\alpha$, and IGF-I
\end{abstract}


were increased $(P<0.05)$ in animals receiving a TI100 over the other two implant dates after OPT was fed to animals. After OPT administration myosin heavy chain IIA (MHC IIA) mRNA levels tended to decrease $(P=0.09)$ due to OPT. An interaction between TI $\mathrm{d}$ and OPT administration caused an increase $(P<0.05)$ in MHC IIA mRNA level in the TI60/Yes treatment group over all other treatments except the TI100/No treatment group. Protein intensity of the $\beta 2$ AR was decreased $(P<0.05)$ by the latest TI $\mathrm{d}$ (TI60) during OPT feeding, while $\beta 1$ AR protein intensity tended to be lower $(P<0.10)$ in animals fed OPT. Plasma BUN levels were reduced $(P<0.05)$ after terminal implants and OPT feeding; while progesterone was decreased $(P<0.05)$ by OPT alone. Neither growth promotant affected NEFA levels in plasma. Collectively, these data indicate that ractopamine hydrochloride and estradiol + trenbolone acetate implants alter myogenic mRNA, $\beta$-adrenergic receptors, and blood metabolites in finishing beef heifers.

\section{Keywords}

$\beta$-Agonist, $\beta$-Receptor, Muscle Hypertrophy, Myogenic mRNA, Ractopamine Hydrochloride, Steroid Hormones

\section{Introduction}

Growth promotants are commonly used throughout the United States beef industry. These techniques include the use of a steroidal implants and the administration of $\beta$-adrenergic receptor agonists ( $\beta$-agonists) in feed. Both of these approved methods result in lean tissue accretion, however, their modes of action are quite different. Steroid hormones are delivered to the animal by an implant inserted into the middle of the ear containing steroids that are released over duration of time. Two commonly used steroid hormones for muscle growth are estradiol-17 $\beta$ (E2, an estrogen) and trenbolone acetate (TBA, a synthetic form of testosterone). Steroids act by working through the somatotropic axis; IGF-I elicits the muscle hypertrophy response in live animals [1]. An increase in IGF-I mRNA [2], satellite cells in muscle tissue [3], and an increase in circulating IGF-I [1] has been documented in steers administered a steroidal implant. Animals provided combined TBA/E2 implants have been shown to increase both average daily gain and feed efficiency, $20 \%$ and $15 \%$ respectively [4] [5] compared with nonimplanted animals.

Like steroidal implants, $\beta$-agonists also have been shown to increase muscling, average daily gain, feed efficiency, and carcass weight [6] [7]. They differ, however, in their mechanism in which they increase growth. Unlike anabolic steroids, the somatotropic axis is not influenced by $\beta$-agonists. Known as repartitioning agents, $\beta$-agonists increase lipolysis, decrease lipogenesis, and increase lean muscle deposition [8] [9]. Work has been done in both steers and heifers, with heifers showing more variability in response to ractopamine-hydrochloride $(\mathrm{RH})$ than steers [10] [11]. 
These two different types of growth promotants have been approved for use in animals at the same time. Data supports that the two work additively together in increasing muscle growth, ADG, HCW, and G:F [12] [13]. An interaction between OPT and implants affected the number of $\beta$-adrenergic receptors in feedlot heifers while a decrease in IGF-I was seen in heifers fed OPT that were reimplanted [13]. Our goal in this study was to determine the effects of OPT administration and terminal implant date on skeletal muscle mRNA, skeletal muscle $\beta_{1}$ - and $\beta_{2}$-adrenergic protein levels, and blood urea nitrogen (BUN), progesterone and non-esterified fatty acids (NEFA) in blood of feedlot heifers.

\section{Materials \& Methods}

The growth performance responses and carcass characteristics from these heifers have been reported previously [14]. All experimental procedures involving the use of animals were submitted, reviewed, and approved by the Texas Tech University Animal Care and Use Committee. The experiment was conducted at the Texas Tech University Burnett Center located approximately $9.7 \mathrm{~km}$ east of New Deal, TX.

\section{Animals.}

A total of 264 heifers of mainly British and British $\times$ Continental crossbreds were received at the Texas Tech University Beef Center at New Deal, TX on May $6^{\text {th }}$ and $7^{\text {th }}$ of 2011. Animals came from different sources and were of varied geographical origins. Heifers were provided access to drinking water, grass hay, and a moderate-concentrate mixed diet upon arrival and placed in dirt pens. An initial processing day was performed on May $8^{\text {th }}, 2011$ in which each heifer was weighed individually, ear tagged with identification, vaccinated with a modified live virus vaccine (Titanium $^{\circledR} 3$, Elanco, Greenfield, IN) and a clostridial bacterin toxoid (Vision ${ }^{\circledR} 7$ with SPUR, Merck Animal Health, Madison, NJ), treated for internal parasites with Ivomec Plus ${ }^{\circledR}$ (Merial, Duluth, GA), and treated metaphylactically with Micotil ${ }^{\circledR}$ (Elanco Animal Health). Heifers were stepped up to a $90 \%$ concentrate diet over the three-week period prior to initiation of the trial.

\section{Experimental design, treatment and pen assignment.}

Heifers were separated into two groups and placed on trial (120 head on May $30^{\text {th }}$ and 96 head on June $\left.13^{\text {th }}\right)$. Treatments were arranged into a $2 \times 3$ factorial with 2 levels of ractopamine $\mathrm{HCl}$ (Optaflexx; Elanco Animal Health; OPT) and 3 different durations of terminal implant windows for a total of 6 treatment groups with 9 replications that were blocked by body weight. OPT treatments included a $0 \mathrm{mg} / \mathrm{hd} \cdot \mathrm{d}^{-1}$ of OPT (Control, $\mathrm{n}=27$ ) and $200 \mathrm{mg} / \mathrm{hd} \cdot \mathrm{d}^{-1}$ of OPT ( $=$ 27). OPT was fed to those animals designated to receive it over the last 28 days of the finishing trial. Terminal steroidal implants (TI) were given to animals in a variation of three implant windows $60 \mathrm{~d}$ pre-slaughter (TI60, $\mathrm{n}=18$ ), $100 \mathrm{~d}$ pre-slaughter (TI100, $\mathrm{n}=18$ ), and $140 \mathrm{~d}$ pre-slaughter (TI140, $\mathrm{n}=18$ ). The terminal implant consisted of a $20 \mathrm{mg}$ estradiol $+200 \mathrm{mg}$ trenbolone acetate implant (Component TE-200 with Tylan; Elanco Animal Health). Heifers receiving 
the TI60 and TI100 treatments were initially implanted on d 0 with $8 \mathrm{mg}$ estradiol $+80 \mathrm{mg}$ trenbolone acetate (Component TE-IH; Elanco Animal Health). Heifers were weighted individually on May $28^{\text {th }}$ and June $11^{\text {th }}, 2011$ and stratified. Individuals were weighed again and placed onto trial on May $30^{\text {th }}$ and June $13^{\text {th }}$, respectively. An average of the two individual weights was used for the initial weight to start the trial. Biopsy samples were taken from the longissimus muscle and serum samples were taken on days $0,40,80,112$, and 140 . The samples were taken from 1 heifer per pen from alternating blocks. Due to the time and preparation it takes to take biopsy samples, blocks were split into two groups with the heavy group ( 30 pens; 5 blocks) starting treatments $14 \mathrm{~d}$ before the light group ( 24 pens; 4 blocks) (Total $n$ of animals biopsied $=30$ ). Blood was drawn from 2 animals per pen $(\mathrm{n}=108)$ on days $0,40,80,112$, and 140 .

Diets were formulated based on those outlined by the [15] for growing/finishing cattle and were prepared at the Burnett Center at Texas Tech Feedmill. All diets were manufactured daily and were fed once daily to cattle at approximately 0900 h. Cattle that were destined for OPT treatment were fed an OPT premix that delivered $200 \mathrm{mg} / \mathrm{hd} \cdot \mathrm{d}^{-1}$ over the last $28 \mathrm{~d}$ of the trial and was formulated to provide $19.2 \mathrm{~g} /$ ton DM of OPT. Monensin sodium and tylosin phosphate were included in the diet at rates of $30 \mathrm{~g} /$ ton and $10 \mathrm{~g} /$ ton DM, respectively. Samples were obtained from the feed bunks at morning feedings to assess DM diet composition on a weekly basis. A monthly composite was put together from a portion of these samples that was submitted for nutrient analysis (Servi-Tech Laboratories, Amarillo, TX) using AOAC approved procedures. Samples were also submitted to a commercial laboratory for analysis of monensin sodium and ractopamine $\mathrm{HCl}$ levels. Cattle were weighed at approximately $0600 \mathrm{~h}$ on $\mathrm{d} 40$, 80,112 with a squeeze chute placed on top of load cells certified by the Texas Department of Agriculture (scale readability $0.454 \mathrm{~kg}$ ). During the weighing period, feed refusals were collected and weighed, and samples were dried to analyze DM content. After individual weights were taken, animals were returned to their respective pens and rations were then provided. Final individual weights and biopsies were taken on d 140 and 141 for the first and second groups respectively (October $17^{\text {th }}$ for the first group and November $1^{\text {st }}$ for the second group).

\section{Biopsy procedure.}

The biopsy procedures were performed at the Burnett Center of Texas Tech University. The procedure comprises of harnessing the animals in a hydraulic chute, shaving the area between the $10^{\text {th }}$ and $13^{\text {th }}$ rib overtop the longissimus dorsi muscle, and applying a local anesthetic (lidocaine HCL; $20 \mathrm{mg} / \mathrm{mL} ; 8 \mathrm{~mL}$ per biopsy) in a $2.54 \mathrm{~cm}$ diamond shape. After application of the local anesthetic, sterile gauze was placed over the biopsy site and an approximately $1-\mathrm{cm}$ incision was made with a sterile scalpel. The tissue sample was extracted with a sterile 6 $\mathrm{mm}$ Bergstrom biopsy needle and was taken from the longissimus dorsi muscle. The tissue taken from the animal was delegated into two whirl-pack bags (Nas- 
co, Fort Atkinson, WI): one intended Real-time quantitative reverse transcription-PCR (RTQ-PCR) and the other for protein quantification via Western Blotting analysis. After tissue extraction, the biopsy site was cleaned and rinsed with a $70 \%$ ethanol solution followed by closure of the incision with veterinary glue. To reduce the chance of infection a topical antibiotic spray was applied to the biopsy site and a spray-on aluminum bandage was used to protect the site from physical entrance. All heifers were monitored for $24 \mathrm{~h}$ for signs of infection and swelling after the biopsy procedure. These procedures were performed on $\mathrm{d} 0$, 40,80 , and 112; location of the site was alternated between sides of the animal for the sequential days. Day 140 samples were obtained from the slaughter plant and were taken from the longissimus muscle after the animals hide was removed. This tissue sample was also located between the $10^{\text {th }}$ and $13^{\text {th }}$ rib. Samples were flash frozen in liquid nitrogen and stored at $-80^{\circ} \mathrm{C}$.

\section{$R N A$ isolation and RTQ-PCR.}

Isolation of RNA was performed using procedures described by [2]. Approximately $0.2 \mathrm{~g}$ of frozen tissue was homogenized in Tri Reagent (Sigma Aldrich, Co.) at a 1:3 ratio of grams of tissue to $\mathrm{mL}$ Tri reagent, by use of mortar and pestle. Then $200 \mu \mathrm{L}$ chloroform was mixed in with the sample in a microcentrifuge tube and then the tube was vortexed for $30 \mathrm{~s}$. After vortexing, the solution was centrifuged at 15,000 $\times g$ and the resulting supernatant was removed and placed into a separate tube. The supernatant was mixed with isopropanol and centrifuged at $10,000 \times g$ for 10 minutes and the resulting pellet was rinsed with a $75 \%$ ethanol solution before being resuspended and frozen in $75 \%$ ethanol. Samples were treated with DNAse to remove any DNA contaminants with a DNA-free kit (Ambion). After DNAse treatment, the concentration of RNA (suspended in nuclease free water after being DNAsed) was determined with a spectrophotometer at an absorbance of $260 \mathrm{~nm}$ to determine RNA quality, a 260/280 ratio of 1.76 to 2.05 was determined to be acceptable. After determining concentration, RNA was then subjected to reverse-transcriptase procedures and cDNA was produced. cDNA was synthesized from $1 \mu \mathrm{g}$ of mRNA using TaqMan Reverse Transcription Reagents (Applied Biosystems, Foster City, CA) with the primers for cDNA synthesis derived from random hexamers.

Real-time quantitative reverse transcription-PCR was used to measure the quantities of $\beta_{1}$-adrenergic receptor ( $\beta 1 \mathrm{AR}$ ), the $\beta_{2}$-adrenergic receptor ( $\beta 2 \mathrm{AR}$ ), myosin heavy chain I (MHC I), myosin heavy chain IIA (MHC IIA), myosin heavy chain IIX (MHC IIX), AMPKa, and IGF-I mRNA. Measurement of cDNA relative quantity to an endogenous control, ribosomal protein S9 (RPS9), was performed by using PCR Master Mix (Applied Biosystems), $300 \mathrm{nM}$ of the appropriate forward and reverse primers and $1 \mu \mathrm{L}$ of the cDNA mixture (Table 1). The cDNA was measured using the ABI Prism 7000 detection system (Applied Biosystems, Foster City, CA) at the recommended thermal cycling variables from the manufacturer ( 40 cycles of $15 \mathrm{~s}$ at $95^{\circ} \mathrm{C}$ and $1 \mathrm{~min}$ at $60^{\circ} \mathrm{C}$ ).

Protein extraction and Western blots. 
Table 1. Forward and reverse primers for RTQ-PCR for myogenic gene expression.

\begin{tabular}{|c|c|}
\hline Item & Sequence ( $5^{\prime}$ to $\left.3^{\prime}\right)$ \\
\hline \multicolumn{2}{|c|}{ AMPK $\alpha$ (accession \# NM_001109802) } \\
\hline Forward & ACCATTCTTGGTTGCTGAAACTC \\
\hline Reverse & CACCTTGGTGTTTGGATTTCTG \\
\hline TaqMan Probe & 6FAM-CAGGGCGCGCCATACCCTTG-TAMRA \\
\hline \multicolumn{2}{|c|}{ IGF-I (accession \# X15726) } \\
\hline Forward & TGTGATTTCTTGAAGCAGGTGAA \\
\hline Reverse & AGCACAGGGCCAGATAGAAGAG \\
\hline TaqMan Probe & 6FAM-TGCCCATCACATCCTCCTCGCA-TAMRA \\
\hline \multicolumn{2}{|c|}{ MHC-I (acession \# AB059400) } \\
\hline Forward & СССАСТТСТСССТGATССАСТАС \\
\hline Reverse & TTGAGCGGGTCTTTGTTTTTCT \\
\hline TaqMan Probe & 6FAM-CCGGCACGGTGGACTACAACATCATAG-TAMRA \\
\hline \multicolumn{2}{|c|}{ MHC-IIa (accession \# AB059398) } \\
\hline Forward & GCAATGTGGAAACGATCTCTAAAGC \\
\hline Reverse & GCTGCTGCTCCTCCTCCTTG \\
\hline TaqMan Probe & 6FAM-TCTGGAGGACCAAGTGAACGAGCTGA-TAMRA \\
\hline \multicolumn{2}{|c|}{ MHC-IIx (accession \# AB059399) } \\
\hline Forward & GGCCСАСТTCTCССТСАTTC \\
\hline Reverse & CCGACCACCGTCTCATTCA \\
\hline TaqMan Probe & 6FAM-CGGGCACTGTGGACTACAACATTACT-TAMRA \\
\hline \multicolumn{2}{|c|}{$\beta 1-\mathrm{AR}$ (accession \# AF188187) } \\
\hline Forward & GTGGGACCGCTGGGAGTAT \\
\hline Reverse & TGACACACAGGGTCTCAATGC \\
\hline TaqMan Probe & 6FAM-СTCCTTCTTCTGCGAGCTCTGGACCTC-TAMRA \\
\hline \multicolumn{2}{|c|}{$\beta 2$-AR (accession \# NM_174231) } \\
\hline Forward & CAGCTCCAGAAGATCGACAAATC \\
\hline Reverse & CTGCTCCACTTGACTGACGTTT \\
\hline TaqMan Probe & 6FAM-AGGGCCGCTTCCATGCCC-TAMRA \\
\hline \multicolumn{2}{|c|}{ RPS9 (accession \# DT860044) } \\
\hline Forward & GAGCTGGGTTTGTCGCAAAA \\
\hline Reverse & GGTCGAGGCGGGACTTCT \\
\hline TaqMan Probe & 6FAM-ATGTGACCCCGCGGAGACCCTTC-TAMRA \\
\hline
\end{tabular}

Protein was extracted by removing approximately $0.35 \mathrm{~g}$ of tissue from biopsy samples. The tissue was then homogenized with Tissue Protein Extraction Reagent (T-PER; Pierce Biotechnology, Rockford, IL) at a ratio of $1 \mathrm{~g}$ tissue: $3 \mathrm{~mL}$ of T-PER. Samples were then centrifuged at $14,000 \times g$ for 5 minutes. The super- 
natant was collected and the samples were then centrifuged again at $2000 \times g$ for 5 minutes to rid the sample of excess debris. Protein concentration was determined using an ND-1000 Spectrophotometer (NanoDrop Technologies, Wilmington, DE) and samples were brought to equal concentration by addition of TPER.

Samples were subjected to denaturation by SDS- $\beta$-mercaptoethanol and incubated for 2 minutes at $95^{\circ} \mathrm{C}$. Total protein $(40 \mu \mathrm{g})$ was separated by gel electrophoresis with Novex 10\% - 20\% Tris-glycine gels (Invitrogen, Carlsbad, CA). The gels were run for approximately $120 \mathrm{~min}$ at $120 \mathrm{~V}$ and $130 \mathrm{~mA}$. Proteins were transferred onto a PVDF membrane (Bio-Rad, Hercules, CA) for $120 \mathrm{~min}$ at $4^{\circ} \mathrm{C}$. Following transfer the membrane was blocked by in blocking solution for 1 hour and then rinsed 3 times in $1 \times$ TBS-Tween solution. The appropriate primary antibody against either the $\beta_{1}$-adrenergic receptor or the $\beta_{2}$-adrenergic receptor (Abcam, Cambridge, MA) was then applied to the membrane and was left overnight at $4^{\circ} \mathrm{C}$. After incubation overnight, the membranes were then pulled from the cold incubation freezer and allowed to warm to room temperature for $30 \mathrm{~min}$. After $30 \mathrm{~min}$, the membranes were then rinsed 3 times in $1 \times$ TBS-Tween solution and then secondary Alexa fluorescent antibodies were added to the membrane and incubated for $1 \mathrm{~h}$. After $1 \mathrm{~h}$, membranes were then rinsed 3 times in TBS-Tween solution, dried, and imaged with QuantityOne software.

\section{Blood parameters.}

Concentrations of NEFA were determined by modification of the enzymatic HR Series NEFA-HR (2) assay (Wako Diagnostics, Richmond, VA) to fit a 96-well format [16]. Briefly, $200 \mu \mathrm{L}$ of the prepared Color Reagent A were added to $5 \mu \mathrm{L}$ of serum or prepared standards in a 96-well plate. Plates were incubated at $37^{\circ} \mathrm{C}$ for $5 \mathrm{~min}$ and then absorbance read using a spectrophotometer at 550 $\mathrm{nm}$. Next, $100 \mu \mathrm{L}$ of prepared Color Reagent B was added to all wells on the 96-well plate. Plates were incubated for an additional $5 \mathrm{~min}$ and read for a second time using a plate reader at $550 \mathrm{~nm}$. Concentrations of NEFA were determined by comparing unknown samples to at standard curve of known NEFA concentrations. The minimum detectable concentration was $0.0014 \mathrm{mEq} / \mathrm{L}$ and the intra- and inter-assay coefficients of variation were $9.0 \%$ and $14.3 \%$, respectively. Data are presented as the concentration in $\mathrm{mEq} / \mathrm{L}$.

Serum concentrations of BUN were determined by a colorimetric assay according to the manufacturer's guidelines (K024-H1; Arbor Assays, Ann Arbor, MI) by comparison of unknowns to standard curves generated with known concentrations of urea nitrogen. The minimum detectable BUN concentration was $0.065 \mathrm{mg} / \mathrm{dL}$ and the intra- and inter-coefficients of variation were $4.0 \%$ and $15.7 \%$, respectively. Data are presented as the concentration in $\mathrm{mg} / \mathrm{dL}$.

For progesterone analysis, serum was sent to New Mexico State University (D. Halford) and analyzed via radioimmunoassay procedure using bovine specific antibodies to determine progesterone concentration.

\section{Statistical analysis.}


Data were analyzed using the PROC Mixed function in SAS 9.4 (SAS Inst., Cary, NC). The data were analyzed as a randomized complete block design using repeated measures over time. The covariance structure with the lowest Akaike information criterion (AIC) was used [17] and the least significance difference procedure of SAS 9.4 was used to determine significance between treatments using an $\alpha$ of 0.05 . The statistical model had protein and mRNA data dependent on the fixed effects of day, TI day, OPT, and all possible interactions and pen served as the experimental unit for all analyses. To give a common starting point for animals receiving OPT administration, covariate analysis was performed on the day OPT was given to the animals. A $\alpha$ of 0.05 determined significance and 0.051 to 0.10 was considered a tendency.

\section{Results}

\section{Individual effects of OPT and TI day on $m R N A$}

Real-time quantitative PCR was performed on the $\beta_{1}$-adrenergic receptor $(\beta 1$ $\mathrm{AR})$, the $\beta_{2}$-adrenergic receptor ( $\beta 2 \mathrm{AR}$ ), myosin heavy chain I (MHC I), myosin heavy chain IIA (MHC IIA), myosin heavy chain IIX (MHC IIX), AMPK $\alpha$, and IGF-I to determine if OPT would alter mRNA levels in longissimus muscle of heifers provided ractopamine $\mathrm{HCl}$. Main effect means are presented in Table 2 and Table 4 (covariate adjusted using $\mathrm{d} 112$ pre-RH biopsy values to adjust in Table 4 for myogenic genes) and interactive means of terminal implant and $\mathrm{RH}$ use are presented in Table 3 and Table 5 (covariate adjusted using d 112 pre-RH biopsy values to adjust in Table 5 for myogenic genes). Over the entire study, it was discovered that OPT did not alter $(P>0.05)$ gene expression of any myogenic mRNA levels (Table 2). Because OPT was administered only over the last

Table 2. The individual effects of terminal implant day (TI day) and ractopamine hydrochloride (OPT) on relative myogenic genes. Values for each parameter are represented by least-square means.

\begin{tabular}{cccccccccc}
\hline \multicolumn{7}{c}{ TI Day $^{2}$} & \multicolumn{7}{c}{ Treatment } \\
\hline \multicolumn{7}{c}{} & \multicolumn{7}{c}{ No } & Yes & SEM $^{4}$ & TI Day & OPT \\
\hline Gene $^{1}$ & TI160 & TI100 & TI60 & SEM & No & \\
\hline B AR & 0.53 & 0.61 & 1.31 & 0.39 & 0.75 & 0.88 & 0.31 & 0.29 & 0.78 \\
$\beta 2$ AR & 1.41 & 1.57 & 1.40 & 0.20 & 1.51 & 1.42 & 0.18 & 0.71 & 0.63 \\
MHC I & $2.15^{*}$ & $3.17^{*}$ & 2.51 & 0.43 & 2.09 & 2.32 & 0.39 & 0.07 & 0.11 \\
MHC IIA & 612.30 & 736.68 & 923.41 & 199.33 & 712.06 & 802.86 & 171.14 & 0.34 & 0.58 \\
MHC IIX & 5.13 & 7.73 & 5.31 & 1.38 & 6.47 & 5.65 & 1.25 & 0.13 & 0.48 \\
AMPK $\alpha$ & 1.65 & 1.88 & 1.48 & 0.20 & 1.69 & 1.65 & 0.17 & 0.26 & 0.86 \\
IGF-1 & 1.93 & 2.39 & 1.72 & 0.32 & 1.92 & 2.11 & 0.29 & 0.13 & 0.49 \\
\hline
\end{tabular}

${ }^{1}$ Genes are as follows: the $\beta-1$ adrenergic receptor ( $\left.\beta 1 \mathrm{AR}\right), \beta-2$ adrenergic receptor $(\beta 2 \mathrm{AR})$, myosin heavy chain I (MHC I), myosin heavy chain IIA (MHC IIA), myosin heavy chain IIX (MHC IIX), AMPK $\alpha$, and IGF-I. ${ }^{2}$ Animals were implanted on d 140 (TI140), 100 (TI100), or 60 (TI60) before slaughter with Component TE-200. ${ }^{3}$ Ractopamine hydrochloride provided to animals at $200 \mathrm{mg} / \mathrm{hd} \cdot \mathrm{d}^{-1}$ in final 28 days of trial. ${ }^{4} \mathrm{SEM}$ represents the pooled standard error of the mean. 
Table 3. The interactive effects of terminal implant day (TI day) and ractopamine hydrochloride (OPT) on relative myogenic genes. Values for each parameter are represented by least-square means.

\begin{tabular}{ccccccccc}
\hline \multicolumn{7}{c}{ Treatment } \\
\hline \multicolumn{7}{c}{ TI Day $^{2} / \mathrm{OPT}^{3}$} \\
\hline Gene $^{1}$ & TI140/No TI140/Yes TI100/No TI100/Yes & TI60/No & TI60/Yes & SEM $^{4}$ & $P$-Value \\
$\beta 1$ AR & 0.7274 & 0.3349 & 0.3193 & 0.8949 & 1.2157 & 1.398 & 0.548 & 0.6695 \\
$\beta 2$ AR & 1.6765 & 1.139 & 1.4328 & 1.7135 & 1.411 & 1.3886 & 0.2637 & 0.2251 \\
MHC I & 2.2821 & 2.024 & 3.4122 & 2.9289 & 3.0133 & 2.0013 & 0.5424 & 0.6925 \\
MHC IIA & $597.93^{\mathrm{a}}$ & $626.67^{\mathrm{a}}$ & $987.57^{\mathrm{ab}}$ & $485.78^{\mathrm{a}}$ & $550.68^{\mathrm{a}}$ & $1296.14^{\mathrm{b}}$ & 261.51 & 0.0103 \\
MHC IIX & 4.9057 & 5.3565 & 8.0575 & 7.4053 & 6.4525 & 4.1774 & 1.7259 & 0.6323 \\
AMPK $\alpha$ & 1.9312 & 1.3636 & 1.8087 & 1.9602 & 1.3234 & 1.6328 & 0.2714 & 0.1776 \\
IGF-1 & 1.9214 & 1.9416 & 2.2609 & 2.5104 & 1.5726 & 1.8762 & 0.404 & 0.905 \\
\hline
\end{tabular}

${ }^{1}$ Genes are as follows: the $\beta$-1 adrenergic receptor ( $\left.\beta 1 \mathrm{AR}\right), \beta$-2 adrenergic receptor ( $\beta 2 \mathrm{AR}$ ), myosin heavy chain I (MHC I), myosin heavy chain IIA (MHC IIA), myosin heavy chain IIX (MHC IIX), AMPK $\alpha$, and IGF-I. ${ }^{2}$ Animals were implanted on d 140 (TI140), 100 (TI100), or 60 (TI60) before slaughter with Component TE-200. ${ }^{3}$ Ractopamine hydrochloride provided to animals at $200 \mathrm{mg} / \mathrm{hd} \cdot \mathrm{d}^{-1}$ in final 28 days of trial. ${ }^{4} \mathrm{SEM}$ represents the pooled standard error of the mean. ${ }^{\text {ab}}$ Values with different superscripts differ $(P<$ $0.05)$.

28 days of feeding, the final biopsy day (Day 112, which initiated ractopamine $\mathrm{HCl}$ administration) before slaughter was used as a covariate. The covariate results showed that all gene quantities, except for MHC IIA, did not differ among treatments (Table 4). MHC IIA expression tended to be lower $(P=0.09)$ in OPT administered animals (Table 4).

RTQ-PCR was also used to determine if terminal implant (TI) day would alter myogenic mRNA levels. Animals that received the TI 100 treatment tended to have a higher level $(P<0.10)$ of MHC I expression in the longissimus muscle than animals that received TI140 (Table 2). No other mRNA levels differed $(P>0.05)$ depending on TI implant strategy (Table 2). Like with OPT, day 112 was used as a covariate to determine if there were any changes in mRNA levels once OPT was administered to the animals. Relative mRNA levels of MHC IIX, AMPK $\alpha$, and IGF-I were greater $(P<0.05)$ in animals receiving TI100 over those receiving TI140 or TI60 (Table 4). No other genes were impacted $(P>$ $0.10)$ by TI day.

\section{Interactive effects of OPT and TI day on $m R N A$}

To determine relative quantities of skeletal muscle mRNA, RTQ-PCR was performed muscle related genes; the $\beta_{1}$-adrenergic receptor $(\beta 1 \mathrm{AR})$, the $\beta_{2}$-adrenergic receptor ( $\beta 2 \mathrm{AR}$ ), myosin heavy chain I (MHC I), myosin heavy chain IIA (MHC IIA), myosin heavy chain IIX (MHC IIX), AMPK $\alpha$, and IGF-I. All mRNA relative levels were corrected to a housekeeping gene (ribosomal protein subunit 9, RPS9) to ensure correct sample base levels. The results showed that interactive effects of OPT and terminal implant day did not alter $(P>0.05) \beta 1$ $\mathrm{AR}, \beta 2 \mathrm{AR}, \mathrm{MHC}$ I, MHC IIX, AMPK $\alpha$, or IGF-I mRNA levels within longissimus 
Table 4. The individual effects of terminal implant day (TI day) and ractopamine hydrochloride (OPT) using day 112 biopsy levels as a covariate on relative myogenic genes. Values for each parameter are represented by least-square means.

\begin{tabular}{cccccccccc}
\hline \multicolumn{7}{c}{ Treatment } \\
\hline \multicolumn{7}{c}{ TI Day $^{2}$} & & \multicolumn{3}{c}{ OPT $^{3}$} & & \multicolumn{2}{c}{$P$-Values } \\
\hline Gene $^{1}$ & TI140 & TI100 & TI60 & SEM & No & Yes & SEM $^{4}$ & TI Day & OPT \\
$\beta 1$ AR & 0.24 & 0.33 & 0.15 & 0.79 & 0.20 & 0.27 & 0.07 & 0.22 & 0.48 \\
$\beta 2$ AR & 2.73 & 3.41 & 2.03 & 0.86 & 3.15 & 2.29 & 0.66 & 0.41 & 0.37 \\
MHC I & 0.67 & 1.18 & 0.90 & 0.23 & 1.05 & 0.79 & 0.20 & 0.13 & 0.20 \\
MHC IIA & 338.93 & 480.44 & 663.37 & 246.56 & 531.20 & 457.29 & 201.81 & 0.59 & 0.09 \\
MHC IIX & $1.76^{\mathrm{a}}$ & $2.91^{\mathrm{b}}$ & $1.51^{\mathrm{a}}$ & 0.55 & 2.09 & 2.03 & 0.48 & 0.08 & 0.91 \\
AMPK $\alpha$ & $1.91^{\mathrm{a}}$ & $3.40^{\mathrm{b}}$ & $1.16^{\mathrm{a}}$ & 0.50 & 2.18 & 2.14 & 0.40 & 0.01 & 0.95 \\
IGF-1 & $3.14^{\mathrm{a}}$ & $5.24^{\mathrm{b}}$ & $2.76^{\mathrm{a}}$ & 0.66 & 3.74 & 3.69 & 0.52 & 0.02 & 0.95 \\
\hline
\end{tabular}

${ }^{1}$ Genes are as follows: the $\beta$-1 adrenergic receptor ( $\left.\beta 1 \mathrm{AR}\right), \beta$-2 adrenergic receptor ( $\left.\beta 2 \mathrm{AR}\right)$, myosin heavy chain I (MHC I), myosin heavy chain IIA (MHC IIA), myosin heavy chain IIX (MHC IIX), AMPK $\alpha$, and IGF-I. ${ }^{2}$ Animals were implanted on d 140 (TI140), 100 (TI100), or 60 (TI60) before slaughter with Component TE-200. ${ }^{3}$ Ractopamine hydrochloride provided to animals at $200 \mathrm{mg} / \mathrm{hd} \cdot \mathrm{d}^{-1}$ in final 28 days of trial. ${ }^{4} \mathrm{SEM}$ represents the pooled standard error of the mean. abValues with different superscripts differ $(P<$ $0.05)$.

muscle biopsies (Figure 1). The MHC IIA isoform gene level was elevated $(P<$ $0.05)$ in animals that received the latest terminal implant plus OPT administration (80/Yes) (Figure 2) over all other treatments accept those animals that received the day 40 terminal implant and were not given OPT (40/No) (Figure 2) The animals in the 40/No treatment group tended to have higher $(P<0.10)$ MHC IIA levels than the group that was implanted on day 40 and received OPT (40/Yes) (Figure 2). To determine if OPT and TI day had an interaction after OPT administration, day 112 was used as a covariate in mRNA analysis. The use of day 112 as a covariate in the analysis of the interactive effects of OPT and TI day showed that there were no difference $(P>0.05)$ in mRNA levels between treatments (Table 5).

\section{Individual effects of OPT and TI day on protein levels}

Data obtained from Western blotting for each protein sample were corrected with a common reference sample. A representation of the $\beta_{1}$-adrenergic receptor and $\beta_{2}$-adrenergic receptor Western blot is shown (Figure 3 ). The quantities of the $\beta_{1}$-adrenergic receptor ( $\beta 1 \mathrm{AR}$ ) and $\beta_{2}$-adrenergic receptor were not affected $(P>0.05)$ by OPT or TI day (Table 6); however, when day 112 (the first day of OPT administration) is used as a covariate of analysis, the $\beta 1 \mathrm{AR}$ tended to be higher $(P<0.10)$ in animals that were not provided OPT than those that were given OPT (Table 7 and Figure 4). An effect of TI day is also documented when day 112 is used as a covariate of analysis. Animals receiving TI60 had lower $\beta 2$ AR intensities than those that received TI140 or TI100. There was no effect $(P>$ $0.05)$ in the covariate of analysis by OPT on the $\beta 2$ AR or by TI day on the $\beta 1$ AR. 


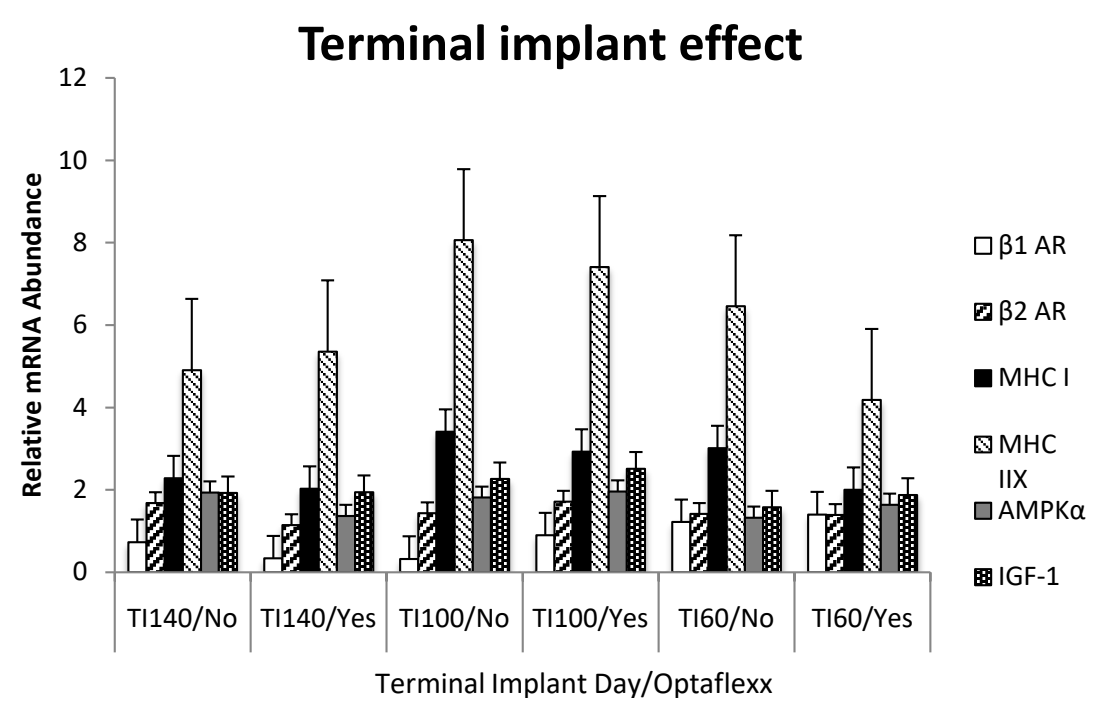

Figure 1. Longissimus muscle $\beta$-1 adrenergic receptor ( $\beta 1 \mathrm{AR}), \beta$-2 adrenergic receptor ( $\beta 2 \mathrm{AR})$, myosin heavy chain I (MHC I), myosin heavy chain IIX (MHC IIX), AMPK $\alpha$, and IGF-I relative mRNA levels of 6 different treatments. The treatments were arranged in a $2 \times 3$ factorial with two treatments of Optaflexx (No-did not receive Optaflexx and Yes-received Optaflexx) and 3 different terminal implant days (TI140, TI100, TI60; relative to slaughter). No differences were observed when comparing treatments among individual genes.

\section{MHC IIA}

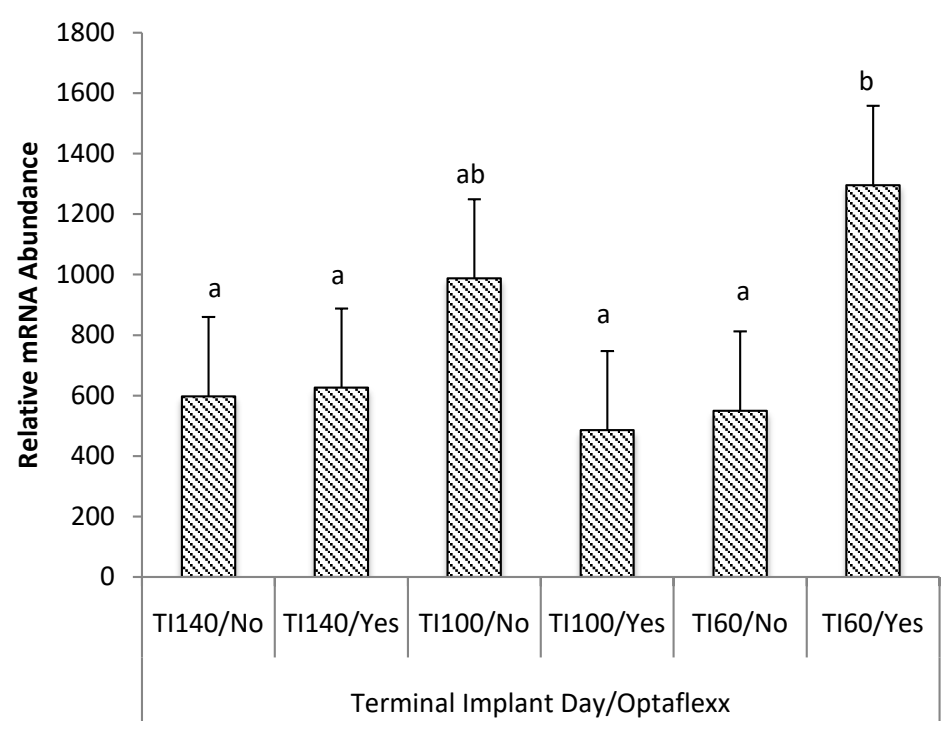

Q MHC IIA

Figure 2. Longissimus muscle myosin heavy chain IIA (MHC IIA) relative mRNA levels of 6 different treatments. The treatments were arranged in a $2 \times 3$ factorial with two treatments of ractopamine-hydrochloride (No-did not receive OPT and Yes-received OPT) and 3 different terminal implant days (TI140, TI100, TI60; relative to slaughter). Pooled standard errors of the mean bars are represented. Bars with different letter designation are different $(P<0.05)$.

Effects of OPT and TI on blood serum parameters

Blood was drawn from 2 animals per pen $(\mathrm{n}=108)$ on days $0,40,80,112$, and 


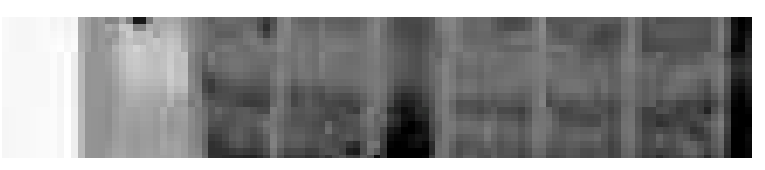

(a)

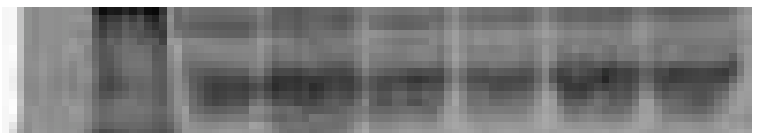

(b)

\section{Implant effect on protein intensity during Optaflexx administration}

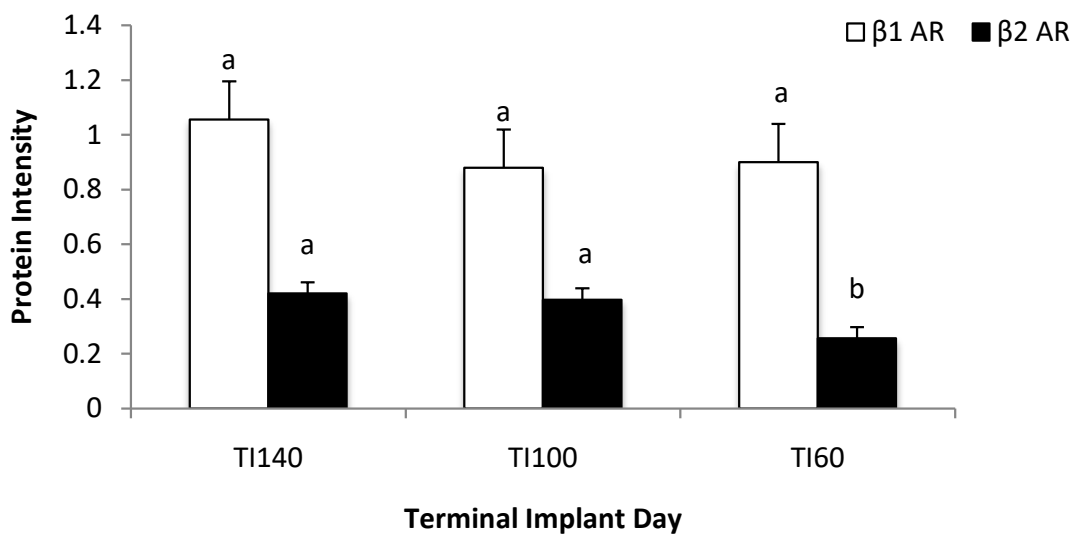

(c)

Figure 3. (a) A representative Western blot of the $\beta_{1}$-adrenergic receptor. (b) A representative Western blot of the $\beta_{2}$-adrenergic receptor. (c) Longissimus muscle $\beta$ - 1 adrenergic receptor $(\beta 1 \mathrm{AR})$ and $\beta$-2 adrenergic receptor $(\beta 2 \mathrm{AR})$ protein intensity during OPT feeding in three TI implant dates (TI140, TI100, TI60; relative to slaughter). All values were corrected to a common reference sample. Pooled standard errors of the mean bars are represented. Bars of the same color with differing superscripts designate a difference in intensity $(P<0.05)$.

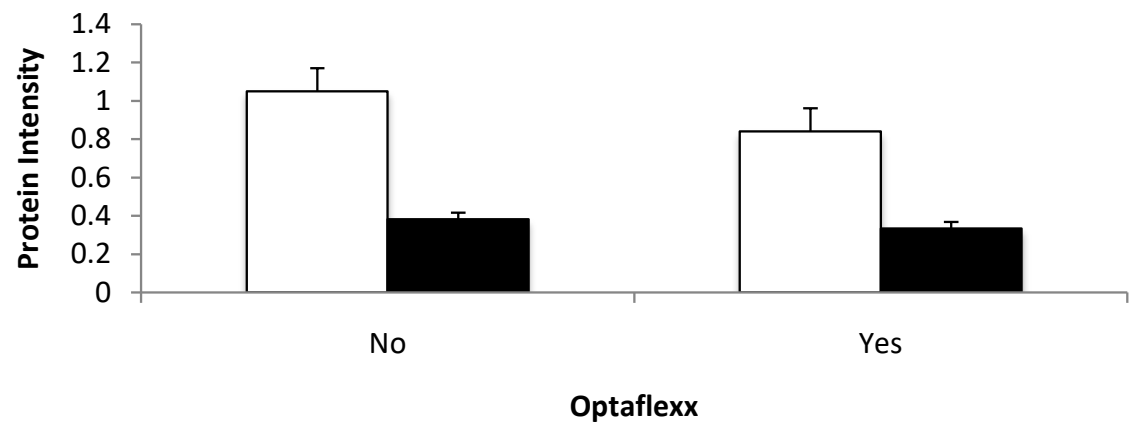

Figure 4. Longissimus muscle $\beta$-1 adrenergic receptor ( $\beta 1 \mathrm{AR})$ and $\beta$-2 adrenergic receptor $(\beta 2 \mathrm{AR})$ protein intensity during OPT feeding; treatments are $0 \mathrm{mg} / \mathrm{hd} \cdot \mathrm{d}^{-1}(\mathrm{No})$ or $200 \mathrm{mg} / \mathrm{hd} \cdot \mathrm{d}^{-1}$ (Yes). All values were corrected to a common reference sample. Pooled standard errors of the mean bars are represented. 
Table 5. The interactive effects of terminal implant day (TI day) and ractopamine hydrochloride (OPT) using day 112 biopsy levels as a covariate on relative myogenic genes. Values for each parameter are represented by least-square means.

\begin{tabular}{|c|c|c|c|c|c|c|c|c|}
\hline \multicolumn{9}{|c|}{ Treatment } \\
\hline \multicolumn{9}{|c|}{ TI $\mathrm{Day}^{2} / \mathrm{OPT}^{3}$} \\
\hline Gene $^{1}$ & TI140/No & TI140/Yes T & TI100/No & TI100/Yes & TI60/No & TI60/Yes & $\mathrm{SEM}^{4}$ & $P$-Value \\
\hline$\beta 1 \mathrm{AR}$ & 0.17 & 0.31 & 0.29 & 0.37 & 0.16 & 0.13 & 0.12 & 0.69 \\
\hline$\beta 2 \mathrm{AR}$ & 3.72 & 1.74 & 3.33 & 3.49 & 2.40 & 1.65 & 1.28 & 0.62 \\
\hline MHC I & 0.90 & 0.45 & 1.12 & 1.25 & 1.13 & 0.67 & 0.29 & 0.40 \\
\hline MHC IIA & 268.81 & 409.04 & 538.35 & 422.54 & 786.47 & 540.28 & 408.61 & 0.19 \\
\hline MHC IIX & 2.20 & 1.33 & 2.48 & 3.34 & 1.60 & 1.42 & 0.73 & 0.42 \\
\hline $\mathrm{AMPK} \alpha$ & 2.27 & 1.55 & 3.25 & 3.55 & 1.00 & 1.32 & 0.74 & 0.70 \\
\hline IGF-1 & 3.70 & 2.57 & 4.73 & 5.76 & 2.78 & 2.75 & 0.98 & 0.49 \\
\hline
\end{tabular}

${ }^{1} \mathrm{Genes}$ are as follows: the $\beta$-1 adrenergic receptor ( $\left.\beta 1 \mathrm{AR}\right), \beta-2$ adrenergic receptor $(\beta 2 \mathrm{AR})$, myosin heavy chain I (MHC I), myosin heavy chain IIA (MHC IIA), myosin heavy chain IIX (MHC IIX), AMPK $\alpha$, and IGF-I. ' Animals were implanted on d 140 (TI140), 100 (TI100), or 60 (TI60) before slaughter with Component TE-200. ${ }^{3}$ Ractopamine hydrochloride provided to animals at $200 \mathrm{mg} / \mathrm{hd} \cdot \mathrm{d}^{-1}$ in final 28 days of trial. ${ }^{4} \mathrm{SEM}$ represents the pooled standard error of the mean.

Table 6. The individual effects of terminal implant day (TI day) and ractopamine hydrochloride (OPT) on protein quantity. Values for each parameter are represented by least-square means.

\begin{tabular}{|c|c|c|c|c|c|c|c|c|c|}
\hline \multirow[b]{3}{*}{ Protein ${ }^{1}$} & \multicolumn{7}{|c|}{ Treatment } & & \\
\hline & \multicolumn{3}{|c|}{ TI Day ${ }^{2}$} & \multicolumn{4}{|c|}{$\mathrm{OPT}^{3}$} & \multicolumn{2}{|c|}{$P$-Values } \\
\hline & TI140 & TI100 & TI60 & SEM & No & Yes & $\mathrm{SEM}^{4}$ & TI Day & OPT \\
\hline$\beta 1 \mathrm{AR}$ & 0.59 & 0.64 & 0.70 & 0.06 & 0.62 & 0.67 & 0.06 & 0.32 & 0.31 \\
\hline$\beta 2 \mathrm{AR}$ & 0.67 & 0.67 & 0.70 & 0.05 & 0.69 & 0.66 & 0.04 & 0.83 & 0.52 \\
\hline
\end{tabular}

${ }^{1}$ Proteins quantified were the $\beta_{1}$ - adrenergic receptor ( $\left.\beta 1 \mathrm{AR}\right)$ and the $\beta_{2}$ - adrenergic receptor $(\beta 2 \mathrm{AR})$. ${ }^{2}$ Animals were implanted on d 140 (TI140), 100 (TI100), or 60 (TI60) before slaughter with Component TE-200. ${ }^{3}$ Ractopamine hydrochloride provided to animals at $200 \mathrm{mg} / \mathrm{hd} \cdot \mathrm{d}^{-1}$ in final 28 days of trial. ${ }^{4} \mathrm{SEM}$ represents the pooled standard error of the mean.

Table 7. The individual effects of terminal implant day (TI day) and ractopamine hydrochloride (OPT) on protein quantity using day 112 as a covariate. Values for each parameter are represented by least-square means.

\begin{tabular}{|c|c|c|c|c|c|c|c|c|c|}
\hline \multicolumn{10}{|c|}{ Treatment } \\
\hline \multirow[b]{2}{*}{ Protein $^{1}$} & \multicolumn{3}{|c|}{ TI Day ${ }^{2}$} & \multicolumn{4}{|c|}{$\mathrm{OPT}^{3}$} & \multicolumn{2}{|c|}{$P$-Values } \\
\hline & TI140 & TI100 & TI60 & SEM & No & Yes & SEM $^{4}$ & TI Day & OPT \\
\hline$\beta 1 \mathrm{AR}$ & 1.0563 & 0.8803 & 0.9003 & 0.14000 & 1.0504 & 0.8409 & 0.12000 & 0.3766 & 0.0748 \\
\hline$\beta 2 \mathrm{AR}$ & $0.421^{\mathrm{a}}$ & $0.3986^{a}$ & $0.2573^{\mathrm{b}}$ & 0.04043 & 0.3832 & 0.3347 & 0.03314 & 0.0185 & 0.3151 \\
\hline
\end{tabular}

${ }^{1}$ Proteins quantified were the $\beta_{1}$, adrenergic receptor $(\beta 1 \mathrm{AR})$ and the $\beta_{2}$, adrenergic receptor $(\beta 2 \mathrm{AR})$. ${ }^{2}$ Animals were implanted on d 140 (TI140), 100 (TI100), or 60 (TI60) before slaughter with Component TE-200. ${ }^{3}$ Ractopamine hydrochloride provided to animals at $200 \mathrm{mg} / \mathrm{hd} \cdot \mathrm{d}^{-1}$ in final 28 days of trial. ${ }^{4} \mathrm{SEM}$ represents the pooled standard error of the mean. 
140 do determine implant and $\beta$-agonist effects on blood urea nitogen (BUN), progesterone, and non-esterified fatty acid (NEFA) content. Upon receiving a terminal implant, BUN was shown to decrease $(P<0.05)$ in blood samples (Figure 5). OPT decreased $(P<0.05)$ both BUN and progesterone concentrations in blood samples (Figure 6 and Figure 7, respectively). Terminal implant did not affect $(P>0.05)$ progesterone levels and neither TI nor OPT altered NEFA level.

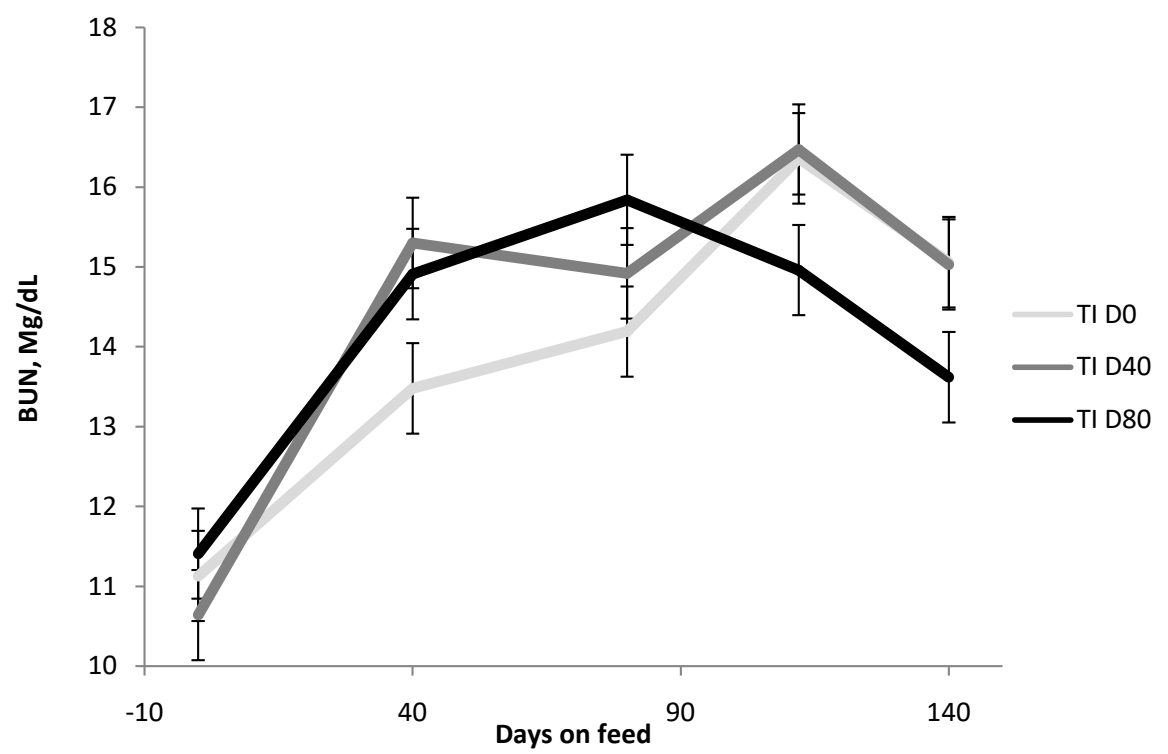

Figure 5. Effect of terminal implant window on blood urea nitrogen (BUN) levels in finishing beef heifers. Cattle implanted with Component TE-200 with Tylan day 140 (TI140), day 100 (TI100), or day 60 (TI60) from slaughter. BUN levels decrease after a terminal implant is administered to the animal.

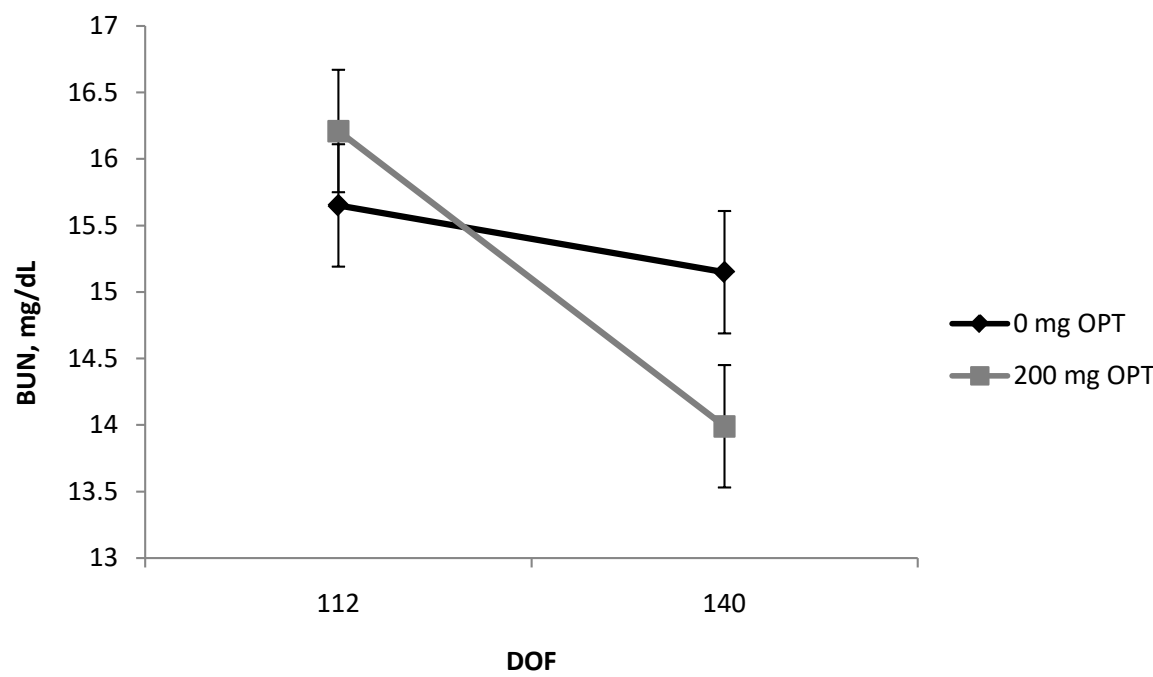

Figure 6. Effect of ractopamine hydrochloride (OPT) on blood urea nitrogen (BUN) levels in finishing beef heifers over days on feed (DOF). Animals were either provided OPT $(200 \mathrm{mg})$ or were not fed OPT $(0 \mathrm{mg})$ over the final 28 days of the trial. On day 140, OPT decreased $(P<0.05)$ BUN. 


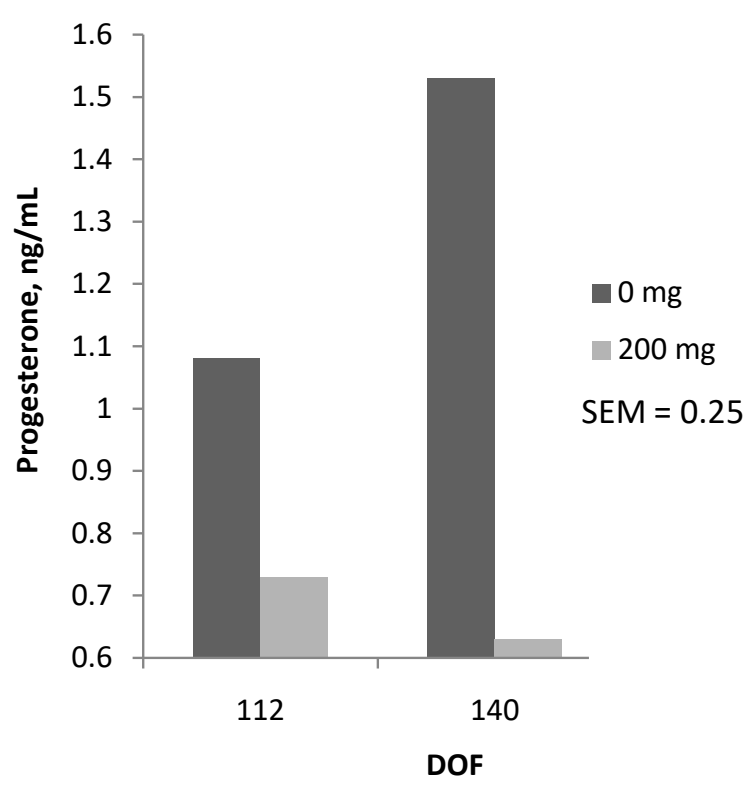

Figure 7. Effect of ractopamine hydrochloride (OPT) on progesterone levels in finishing beef heifers over days on feed (DOF). Animals were either provided OPT $(200 \mathrm{mg})$ or were not fed OPT $(0 \mathrm{mg})$ over the final 28 days of the trial. On day 140 , OPT decreased $(P$ $<0.05)$ progesterone.

\section{Discussion}

Relative mRNA levels over the course of the study did not differ depending on OPT administration or TI day. Spurlock, Cusumano, Ji, Anderson, Smith, Hancock and Mills [18] reported that no $\beta$-adrenergic receptors ( $\beta \mathrm{AR})$ were decreased in pig LM and the same conclusion was reached by [19]. In contrast, [20] showed that ractopamine decreased both $\beta 1$ AR mRNA expression in steers and heifers, but found that steers showed a decrease in $\beta 2$ AR mRNA early on in feeding and an increase in $\beta 2$ AR mRNA later. The group reported that the $\beta 2$ AR mRNA was not affected in heifers fed ractopamine. Sissom, Reinhardt, Johnson, Yates, Hutcheson, Nichols and Swingle [13] saw that $\beta 2$ AR mRNA expression was increased in heifers administered OPT, while $\beta 1$ AR mRNA levels were unchanged by OPT. Winterholler, Parsons, Walker, Quinn, Drouillard and Johnson [21] reported that steers fed ractopamine had an increase in expression of $\beta 2$ AR mRNA, however, [21] only found a tendency to increase $\beta 1$ AR mRNA, with no change in $\beta 2$ mRNA levels. From the point that OPT was fed until slaughter, we found no difference in expression of $\beta 1 \mathrm{AR}$ or $\beta 2 \mathrm{AR}$ mRNA due to ractopamine. Weber, Dikeman, Unruh, Jaeger, Murray, Houser and Johnson [22] reported that in cows fed OPT, $\beta 2$ AR mRNA increased and those that were fed zilpaterol-hydrochloride $(\mathrm{ZH})$ tended to increase $\beta 2 \mathrm{AR}$ mRNA abundance. Variation, especially in heifers, is commonly reported in $\beta$-adrenergic receptor mRNA expression, and could be influenced by many factors such as sex, age, breed, and management practices.

Gunawan, Richert, Schinckel, Grant and Gerrard [23] reported that in pigs fed ractopamine $\mathrm{HCl}$, MHC I expression was not affected, while MHC IIA and 
MHC IIX were both shown to decrease during ractopamine $\mathrm{HCl}$ feeding. The group did see an increase in MHC IIB, but this isoform of the MHC is not expressed in bovine species. Weber, Dikeman, Unruh, Jaeger, Murray, Houser and Johnson [22] showed that during $\beta$-agonist feeding in cull cows, there is a reduction in MHC IIA mRNA expression and an increase in MHC IIX mRNA expression. Another study on cull cows found that when ractopamine was fed at 100 $\mathrm{mg} /$ head/day, a decrease in MHC I and MHC IIX mRNA was recorded, albeit when the dosage was increased to $200 \mathrm{mg} / \mathrm{head} /$ day there was an increase in MHC IIX mRNA [24]. Baxa, Hutcheson, Miller, Brooks, Nichols, Streeter, Yates and Johnson [25] showed that ZH had no effect on MHC I mRNA expression, however, it increased MHC IIX mRNA, and while this is a different $\beta$-agonist than what we used, they still work through the same mechanism. Our results did not support most of these findings; where we had no differences in $\beta A R$ mRNA levels or MHC I and MHC IIX mRNA, we did find a tendency for MHC IIA mRNA to decrease while ractopamine was fed. It could be possible that regulation of these MHC isoforms is partly regulated at the mRNA level, but is also controlled at the protein level by another factor, such as degradation.

Interestingly over the final 28 days of the trial (which is when OPT was fed), an increase in MHC IIX, AMPK $\alpha$, and IGF-I mRNA was found in the LM muscle of animals that received TI100 over those that received the other two TI days. IGF-I mRNA was shown to be decreased in heifers that were implanted with 20 mg estradiol $+200 \mathrm{mg}$ trenbolone acetate (Revalor-200, Merck Animal Health), reimplanted with $200 \mathrm{mg}$ trenbolone (Finaplix-H, Merck Animal Health), and fed ractopamine $\mathrm{HCl}$; while IGF-I mRNA levels were shown to numerically increase in heifers implanted with Revalor-200 and fed ractopamine, but not reimplanted [13]. It is already been shown [1] [26] that steroidal hormones increase IGF-I circulation, so this is not a surprise. What is fairly unique about this increase in IGF-I is that it only occurred after OPT was fed to the animals. Miller, Chung, Hutcheson, Yates, Smith and Johnson [27] showed that in muscle cultures, $\mathrm{ZH}$ tended to increase IGF-I mRNA, while [28] found that Holstein steers fed OPT had decreased serum IGF-I. It is possible that any effects of OPT on IGF-I mRNA abundance in our study were negated by steroidal implants, since all heifers in the study were implanted. An increase MHC IIX mRNA is not supported by results from [29]; their data show that steroidal hormonal implants did not alter any MHC mRNA isoform. Differing results were obtained by [25] in which animals fed $\mathrm{ZH}$, and given the steroidal hormone implant containing (24 mg estradiol $+120 \mathrm{mg}$ trenbolone acetate, Revalor-S, Merck Animal Health) tended to increase MHC IIA expression due to the implant. We only saw an increase in MHC IIX mRNA in the final 28 days on feed, which is also when OPT was given to the animals so there may be an underlying mechanism in which these growth promotants work together.

For instance, an interaction between OPT and TI day was seen in MHC IIA mRNA expression. Animals that received the latest TI (TI60) and ractopamine expressed greater levels of MHC IIA mRNA than any other treatment except 
those that received a terminal implant on day 40 and were not administered OPT. From this, it appears that MHC IIA mRNA expression may be elevated by a hormonal implant, however, its effect recede as its implantation time increases. An elevation in MHC IIA mRNA expression was also described by [25]. Data gathered on $\beta$-agonists' effect on MHC IIA mRNA show that it decreases or does not its expression [25] [29]. It is unclear whether steroid hormones and $\beta$-agonists are working together to cause this increase in MHC IIA, or whether the estradiol and trenbolone acetate implant is solely responsible.

Protein data collected showed that there was no effect due to either TI day or OPT administration over the entire feeding trial. However, during OPT feeding, Optaflexx tended to decrease $\beta 1$ AR protein intensity, while animals that received TI60 showed a decrease in $\beta 2$ AR protein intensity when compared to both TI140 and TI100 heifers. No interaction was discovered to alter protein abundance between the TI day and OPT. In swine, ractopamine $\mathrm{HCl}$ feeding has been shown to decrease $\beta 1 \mathrm{AR}$ in adipose tissue, however, skeletal muscle $\beta 1 \mathrm{AR}$ protein was not affected [18]. Previous research perfomed by [27] indicated that when $\mathrm{ZH}$ is administered to bovine satellite cells, a decrease in $\beta 2 \mathrm{AR}$ protein content resulted. Huang, Gazzola, Pegg and Sillence [30] discovered that in rats given clenbuterol that there is a decrease in $\beta 2 \mathrm{AR}$ protein quantity associated with skeletal muscle. It is speculated that the majority of the action associated with $\mathrm{ZH}$ and/or clenbuterol is mediated though the $\beta 2 \mathrm{AR}$, while OPT possibly works mainly through the $\beta 1 \mathrm{AR}$. Because of this receptor specific association of $\beta$-agonists, it may be possible that the receptor that is stimulated by the $\beta$-agonist may decrease in expression due to stimulation. Data gathered by our study and others would support this receptor reduction theory.

Adrenal steroid hormones have been shown to enhance $\beta 2$ AR actions [31]. Not only are actions enhanced, but cortisone acetate was found to increase $\beta$-adrenergic receptor density in human leukocytes [32]. Not only have adrenal steroids been shown to alter $\beta$-adrenergic receptor number but estrogen and progesterone also may alter receptor protein abundance. Moawad, River and Kilpatrick [33] discovered that in lung tissue of rabbits provided estrogen, $\beta \mathrm{AR}$ abundance increased when compared to controls while progesterone decreased $\beta \mathrm{AR}$ abundance. In rodents' brown adipose tissue testosterone has been shown to not alter $\beta$ AR numbers, however, both estrogen and progesterone could possibly increase $\beta$ AR protein concentration [34]. As mentioned earlier, our results showed that $\beta 2$ AR protein content were elevated in animals that received TI earlier once $\beta$-agonist administration began. The shortest TI day may not have had time to increase signaling that would cause protein expression to elevate, while the earlier two TI days had appropriate amount of time to alter protein abundance. Because the implant used contained both estradiol and TBA, we believe that this increase in $\beta 2 \mathrm{AR}$ quantity is due to estrogenic steroids and not TBA, as supported by research by [34].

The data regarding progesterone is considered novel in that OPT induced reduction of progesterone has not been reported. Progesterone is known as an an- 
ti-anabolic hormone [13], so a decrease in progesterone caused by OPT may allow for enhanced muscle growth. A reduction in BUN due to a $\beta$-agonist indicates a possible increase in protein deposition, as muscle decreases circulating BUN levels. Our results of beta adrenergic agonist decreasing BUN are supported by others [20] [35]. Rathmann, Bernhard, Johnson, Brooks, Miller, Swingle, Lawrence, Yates, Hutcheson, Streeter and Nichols [36] developed a carcass prediction equation and the use of this equation predicts that ADG was increased after each terminal implant. This also supports a reduction in BUN concentration, which caused us to believe that this reduction is indicative of protein accretion in muscle similar to that found by [37]. Heitzman and Chan [37] also found that there was no relation between implants and NEFA levels.

\section{Conclusion}

Collectively, these data indicate that ractopamine $\mathrm{HCl}$ and estradiol + trenbolone acetate implants alter myogenic mRNA, $\beta$-adrenergic receptors, and blood metabolites in finishing beef heifers.

\section{Supported}

Supported in part by funding from Elanco Animal Health, Greenfield, Indiana, and the Gordon W. Davis Regent's Chair in Meat and Muscle Biology Endowment at Texas Tech University, Lubbock.

\section{Conflicts of Interest}

The authors declare no conflicts of interest regarding the publication of this paper.

\section{References}

[1] Johnson, B., Hathaway, M., Anderson, P., Meiske, J. and Dayton, W. (1996) Stimulation of Circulating Insulin-Like Growth Factor I (IGF-I) and Insulin-Like Growth Factor Binding Proteins (IGFBP) Due to Administration of a Combined Trenbolone Acetate and Estradiol Implant in Feedlot Cattle. Journal of Animal Science, 74, 372-379. https://doi.org/10.2527/1996.742372x

[2] Pampusch, M.S., Johnson, B.J., White, M.E., Hathaway, M.R., Dunn, J.D., Waylan, A.T. and Dayton, W.R. (2003) Time Course of Changes in Growth Factor mRNA Levels in Muscle of Steroid-Implanted and Nonimplanted Steers. Journal of Animal Science, 81, 2733-2740. https://doi.org/10.2527/2003.81112733x

[3] Johnson, B.J., Halstead, N., White, M.E., Hathaway, M.R., DiCostanzo, A. and Dayton, W.R. (1998) Activation State of Muscle Satellite Cells Isolated from Steers Implanted with a Combined Trenbolone Acetate and Estradiol Implant. Journal of Animal Science, 76, 2779-2786. https://doi.org/10.2527/1998.76112779x

[4] Johnson, B., Anderson, P., Meiske, J. and Dayton, W. (1996) Effect of a Combined Trenbolone Acetate and Estradiol Implant on Feedlot Performance, Carcass Characteristics, and Carcass Composition of Feedlot Steers. Journal of Animal Science, 74, 363-371. https://doi.org/10.2527/1996.742363x

[5] Bartle, S., Preston, R., Brown, R. and Grant, R. (1992) Trenbolone Acetate/Estradiol 
Combinations in Feedlot Steers: Dose-Response and Implant Carrier Effects. Journal of Animal Science, 70, 1326-1332. https://doi.org/10.2527/1992.7051326x

[6] Abney, C.S., Vasconcelos, J.T., McMeniman, J.P., Keyser, S.A., Wilson, K.R., Vogel, G.J. and Galyean, M.L. (2007) Effects of Ractopamine Hydrochloride on Performance, Rate and Variation in Feed Intake, and Acid-Base Balance in Feedlot Cattle. Journal of Animal Science, 85, 3090-3098. https://doi.org/10.2527/jas.2007-0263

[7] Scramlin, S.M., Platter, W.J., Gomez, R.A., Choat, W.T., McKeith, F.K. and Killefer, J. (2010) Comparative Effects of Ractopamine Hydrochloride and Zilpaterol Hydrochloride on Growth Performance, Carcass Traits, and Longissimus Tenderness of Finishing Steers. Journal of Animal Science, 88, 1823-1829. https://doi.org/10.2527/jas.2009-2405

[8] Mersmann, H.J. (1998) Overview of the Effects of Beta-Adrenergic Receptor Agonists on Animal Growth Including Mechanisms of Action. Journal of Animal Science, 76, 160-172. https://doi.org/10.2527/1998.761160x

[9] Ricks, C.A., Dalrymple, R.H., Baker, P.K. and Ingle, D.L. (1984) Use of a $\beta$-Agonist to Alter Fat and Muscle Deposition in Steers. Journal of Animal Science, 59, 1247-1255. https://doi.org/10.2527/jas1984.5951247x

[10] Quinn, M.J., Reinhardt, C.D., Loe, E.R., Depenbusch, B.E., Corrigan, M.E., May, M.L. and Drouillard, J.S. (2008) The Effects of Ractopamine-Hydrogen Chloride (Optaflexx) on Performance, Carcass Characteristics, and Meat Quality of Finishing Feedlot Heifers. Journal of Animal Science, 86, 902-908. https://doi.org/10.2527/jas.2007-0117

[11] Montgomery, J.L., Krehbiel, C.R., Cranston, J.J., Yates, D.A., Hutcheson, J.P., Nichols, W.T., Streeter, M.N., Swingle, R.S. and Montgomery, T.H. (2009) Effects of Dietary Zilpaterol Hydrochloride on Feedlot Performance and Carcass Characteristics of Beef Steers Fed with and without Monensin and Tylosin. Journal of Animal Science, 87, 1013-1023. https://doi.org/10.2527/jas.2008-1169

[12] Winterholler, S.J., Parsons, G.L., Reinhardt, C.D., Hutcheson, J.P., Nichols, W.T., Yates, D.A., Swingle, R.S. and Johnson, B.J. (2007) Response to Ractopamine-Hydrogen Chloride Is Similar in Yearling Steers across Days on Feed. Journal of Animal Science, 85, 413-419. https://doi.org/10.2527/jas.2006-555

[13] Sissom, E.K., Reinhardt, C.D., Johnson, B.J., Yates, D.A., Hutcheson, J.P., Nichols, W.T. and Swingle, R.S. (2007) Response to Ractopamine- $\mathrm{HCl}$ in Heifers Is Altered by Implant Strategy across Days on Feed. Journal of Animal Science, 85, 2125-2132. https://doi.org/10.2527/jas.2006-660

[14] Jennings, M.A., Ribeiro, F.R.B., Young, T.R., Cribbs, J.T., Bernhard, B.C., Hosford, A.D., Harris, T.L., Anderson, M.J., Vogel, G.J., Scanga, J.A., Miller, M.F. and Johnson, B.J. (2015) Ractopamine Hydrochloride and Estradiol-Trenbolone Acetate Implants Alter Live Performance and Carcass Components of Heifers during the Finishing Phase. The Professional Animal Scientist, 31, 543-551.

https://doi.org/10.15232/pas.2014-01370

[15] NRC (1996) Nutrient Requirements of Beef Cattle. 7th Edition, Natl. Acad. Press, Washington DC.

[16] Smith, Z.K., Thompson, A.J., Hutcheson, J.P., Nichols, W.T. and Johnson, B.J. (2018) Evaluation of Coated Steroidal Implants Containing Trenbolone Acetate and Estradiol-17 $\beta$ on Live Performance, Carcass Traits, and Sera Metabolites in Finishing Steers. Journal of Animal Science, 96, 1704-1723. https://doi.org/10.1093/jas/sky095

[17] Littell, R.C., Henry, P.R. and Ammerman, C.B. (1998) Statistical Analysis of Re- 
peated Measures Data Using SAS Procedures. Journal of Animal Science, 76, 1216-1231. https://doi.org/10.2527/1998.7641216x

[18] Spurlock, M.E., Cusumano, J.C., Ji, S.Q., Anderson, D.B., Smith, C.K. II, Hancock, D.L. and Mills, S.E. (1994) The Effect of Ractopamine on $\beta$-Adrenoceptor Density and Affinity in Porcine Adipose and Skeletal Muscle Tissue. Journal of Animal Science, 72, 75-80. https://doi.org/10.2527/1994.72175x

[19] Smith, C.K. (1989) Affinity of Phenethanolamines for Skeletal Muscle $\beta$-Adrenoceptors and Influence on Receptor Downregulation. Journal of Animal Science, 67, 190.

[20] Walker, D.K., Titgemeyer, E.C., Baxa, T.J., Chung, K.Y., Johnson, D.E., Laudert, S.B. and Johnson, B.J. (2010) Effects of Ractopamine and Sex on Serum Metabolites and Skeletal Muscle Gene Expression in Finishing Steers and Heifers. Journal of Animal Science, 88, 1349-1357. https://doi.org/10.2527/jas.2009-2409

[21] Winterholler, S.J., Parsons, G.L., Walker, D.K., Quinn, M.J., Drouillard, J.S. and Johnson, B.J. (2008) Effect of Feedlot Management System on Response to Ractopamine- $\mathrm{HCl}$ in Yearling Steers. Journal of Animal Science, 86, 2401-2414. https://doi.org/10.2527/jas.2007-0482

[22] Weber, M.J., Dikeman, M.E., Unruh, J.A., Jaeger, J.R., Murray, L., Houser, T.A. and Johnson, B.J. (2012) Effects of Sequential Feeding of $\beta$-Adrenergic Agonists on Cull Cow Performance, Carcass Characteristics, and mRNA Relative Abundance. Journal of Animal Science, 90, 1628-1637. https://doi.org/10.2527/jas.2011-4285

[23] Gunawan, A.M., Richert, B.T., Schinckel, A.P., Grant, A.L. and Gerrard, D.E. (2007) Ractopamine Induces Differential Gene Expression in Porcine Skeletal Muscles. Journal of Animal Science, 85, 2115-2124. https://doi.org/10.2527/jas.2006-540

[24] Gonzalez, J.M., Dijkhuis, R.D., Johnson, D.D., Carter, J.N. and Johnson, S.E. (2008) Differential Response of Cull Cow Muscles to the Hypertrophic Actions of Ractopamine-Hydrogen Chloride. Journal of Animal Science, 86, 3568-3574. https://doi.org/10.2527/jas.2008-1049

[25] Baxa, T., Hutcheson, J., Miller, M., Brooks, J., Nichols, W., Streeter, M., Yates, D. and Johnson, B. (2010) Additive Effects of a Steroidal Implant and Zilpaterol Hydrochloride on Feedlot Performance, Carcass Characteristics, and Skeletal Muscle Messenger Ribonucleic Acid Abundance in Finishing Steers. Journal of Animal Science, 88, 330-337. https://doi.org/10.2527/jas.2009-1797

[26] Pampusch, M.S., White, M.E., Hathaway, M.R., Baxa, T.J., Chung, K.Y., Parr, S.L., Johnson, B.J., Weber, W.J. and Dayton, W.R. (2008) Effects of Implants of Trenbolone Acetate, Estradiol, or Both, on Muscle Insulin-Like Growth Factor-I, Insulin-Like Growth Factor-I Receptor, Estrogen Receptor- $\alpha$, and Androgen Receptor Messenger Ribonucleic Acid Levels in Feedlot Steers. Journal of Animal Science, 86, 3418-3423. https://doi.org/10.2527/jas.2008-1085

[27] Miller, E.K., Chung, K.Y., Hutcheson, J.P., Yates, D.A., Smith, S.B. and Johnson, B.J. (2012) Zilpaterol Hydrochloride Alters Abundance of $\beta$-Adrenergic Receptors in Bovine Muscle Cells But Has Little Effect on de Novo Fatty Acid Biosynthesis in Bovine Subcutaneous Adipose Tissue Explants. Journal of Animal Science, 90, 1317-1327. https://doi.org/10.2527/jas.2011-4589

[28] Walker, D.K., Titgemeyer, E.C., Sissom, E.K., Brown, K.R., Higgins, J.J., Andrews, G.A. and Johnson, B.J. (2007) Effects of Steroidal Implantation and Ractopamine- $\mathrm{HCl}$ on Nitrogen Retention, Blood Metabolites and Skeletal Muscle Gene Expression in Holstein Steers. Journal of Animal Physiology and Animal Nutrition, 91, 439-447. https://doi.org/10.1111/j.1439-0396.2007.00675.x 
[29] Chung, K., Baxa, T., Parr, S., Luqué, L. and Johnson, B. (2012) Administration of Estradiol, Trenbolone Acetate, and Trenbolone Acetate/Estradiol Implants Alters Adipogenic and Myogenic Gene Expression in Bovine Skeletal Muscle. Journal of Animal Science, 90, 1421-1427. https://doi.org/10.2527/jas.2010-3496

[30] Huang, H., Gazzola, C., Pegg, G.G. and Sillence, M.N. (2000) Differential Effects of Dexamethasone and Clenbuterol on Rat Growth and on $\beta 2$-Adrenoceptors in Lung and Skeletal Muscle. Journal of Animal Science, 78, 604-608.

https://doi.org/10.2527/2000.783604x

[31] Davies, A.O. and Lefkowitz, R.J. (1984) Regulation of Beta-Adrenergic Receptors by Steroid Hormones. Annual Review of Physiology, 46, 119-130. https://doi.org/10.1146/annurev.ph.46.030184.001003

[32] Davies, A.O. and Lefkowitz, R.J. (1980) Corticosteroid-Induced Differential Regulation of $\beta$-Adrenergic Receptors in Circulating Human Polymorphonuclear Leukocytes and Mononuclear Leukocytes. The Journal of Clinical Endocrinology \& Metabolism, 51, 599-605. https://doi.org/10.1210/jcem-51-3-599

[33] Moawad, A.H., River, L.P. and Kilpatrick, S.J. (1982) The Effect of Estrogen and Progesterone on Beta-Adrenergic Receptor Activity in Rabbit Lung Tissue. American Journal of Obstetrics and Gynecology, 144, 608-613. https://doi.org/10.1016/0002-9378(82)90235-6

[34] Monjo, M., Rodriguez, A.M., Palou, A. and Roca, P. (2003) Direct Effects of Testosterone, 17 Beta-Estradiol, and Progesterone on Adrenergic Regulation in Cultured Brown Adipocytes: Potential Mechanism for Gender-Dependent Thermogenesis. Endocrinology, 144, 4923-4930. https://doi.org/10.1210/en.2003-0537

[35] Parr, S., Brown, T., Ribeiro, F., Chung, K., Hutcheson, J., Blackwell, B., Smith, P. and Johnson, B. (2014) Biological Responses of Beef Steers to Steroidal Implants and Zilpaterol Hydrochloride. Journal of Animal Science, 92, 3348-3363. https://doi.org/10.2527/jas.2013-7221

[36] Rathmann, R.J., Bernhard, B.C., Johnson, B.J., Brooks, J.C., Miller, M.F., Swingle, R.S., Lawrence, T.E., Yates, D.A., Hutcheson, J.P., Streeter, M.N. and Nichols, W.T. (2012) Effects of Zilpaterol Hydrochloride and Days on the Finishing Diet on Feedlot Performance, Carcass Characteristics, and Tenderness in Beef Heifers. Journal of Animal Science, 90, 3301-3311. https://doi.org/10.2527/jas.2011-4375

[37] Heitzman, R.J. and Chan, K.H. (1974) Alterations in Weight Gain and Levels of Plasma Metabolites, Proteins, Insulin and Free Fatty Acids Following Implantation of an Anabolic Steroid in Heifers. British Veterinary Journal, 130, 532-537. https://doi.org/10.1016/S0007-1935(17)35739-1 